\title{
Prevalence and predictors of occupational asthma among workers in detergent and cleaning products industry and its impact on quality of life in El Asher Men Ramadan, Egypt
}

\author{
Amani Shawki Ahmed ${ }^{1} \cdot$ Dalia Anas Ibrahim² Tarek Hamdy Hassan $^{2} \cdot$ Wael Galal Abd-El-Azem ${ }^{1}$
}

Received: 13 September 2021 / Accepted: 4 January 2022 / Published online: 15 January 2022

(c) The Author(s) 2022

\begin{abstract}
Cleaning products are mixtures of many chemical ingredients that are known to contain sensitizers, disinfectants, and fragrances, as well as strong airway irritants which associated with lower respiratory tract and asthma symptoms.

The aim of this study is to assess the prevalence and possible risk factors of occupational asthma and its effect on quality of life among workers in detergent and cleaning products industries in El Asher men Ramadan city.

This cross-sectional study was conducted on 780 workers. All participants were personally interviewed at their workplaces and were subjected to a questionnaire regarding sociodemographic, work characteristics and asthma symptoms, clinical examination, chest X-ray, spirometer, and bronchodilator test.

The prevalence of occupational asthma among the studied workers was 35.4\%. Multivariate logistic regression analysis revealed that female gender [odds ratio $1.397 ; 95 \%$ CI 1.09-1.96], manually working participants [odds ratio 3.067; 95\% CI 1.72-5.46], and history of atopy [odds ratio 1.596; 95\% CI 1.09-2.33] were risk factors for development of occupational asthma. The total mean score of asthma-specific quality of life was significantly lower in asthmatic $(5.10 \pm 0.49)$ than nonasthmatic workers $(5.89 \pm 0.46)(\mathrm{P}<0.01)$ indicating impairment of quality of life among asthmatic group.

Workers in detergent and cleaning products industry are at higher risk for developing occupational asthma that adversely affects their general health and quality of life.
\end{abstract}

Keywords Occupational asthma $\cdot$ Detergent $\cdot$ Cleaning products $\cdot$ Asthma-specific quality of life

\section{Introduction}

The respiratory health problems have been reported in workers exposed to a variety of occupational exposures during their work processing (Baur and Bakehe, 2014). Respiratory disorders caused by occupational exposures are influenced by type of offending dust, dose, duration of exposure, and genetic factors (Subbarao et al., 2009).

Communicated by Lotfi Aleya.

Amani Shawki Ahmed

dr_amanishawki@yahoo.com; asabdella@zu.edu.eg

1 Community, Environmental and Occupational Medicine Department, Faculty of Medicine, Zagazig University, Zagazig, Egypt

2 Chest Department, Faculty of Medicine, Zagazig University, Zagazig, Egypt
Chemical substances used in cleaning products including enzymes and powder which are respiratory sensitizers are known to cause occupational asthma among worker. It is also an irritant and may give rise to short-term or long-term respiratory disorder up to chronic bronchitis (Dykewicz, 2009; Moscato et al., 2012).

Previous studies on assessing occupational asthma have shown that the proportion of adult asthma cases attributable to occupational exposure is between 10 and 15\% (Mwanga \& Jeebhay, 2013), while the prevalence of occupational asthma associated with exposure to cleaning products was $12 \%$ of the confirmed cases of work-related asthma (Rosenman et al. 2003).

The oxidative stress response has recently been linked to asthma in cleaners who work in hazardous environments (Folletti et al., 2017). Radon et al. (2016) reported that the increased asthma frequency in cleaners could be explained by poor psychosocial working conditions and a stressinduced inflammatory response mechanism. Furthermore, 
early life exposure appears to have a role in the airway vulnerability of cleaners exposed later in life (Svanes et al., 2015).

In order to limit the risk of occupational allergy and asthma, guidelines for the safe handling of enzymes have been established in the detergent sector (Adisesh et al, 2011). Prospective surveillance for the development of enzyme-specific IgE antibody before the emergence of allergic symptoms is essential to the efficacy of the management of enzyme-induced allergy and asthma (Sarlo et al., 2010).

Asthma is frequently associated with psychiatric disorders such as mood and anxiety disorders, and individuals with depressive disorders have been demonstrated to have worse asthma control and a poor quality of life (QOL) (Eisner et al., 2005; Lavoie et al., 2009). Patients with psychiatric comorbidity tend to use more health care than those without it (Richardson et al., 2008).

Coverage and researches for occupational asthma were limited in Egypt especially among workers in detergent and cleaning products industry and its impact on quality in life. The current study aimed to assess the prevalence and possible risk factors of occupational asthma and its effect on quality of life among workers in detergent and cleaning products industries in El Asher men Ramadan city.

\section{Subjects and method}

\section{Study population}

This cross-sectional study was conducted on workers in detergent and cleaning product factories in El Asher men Ramadan city. Data were collected during 6 months from start of May 2020 to the end October 2020.

\section{Sample size and sampling technique}

the prevalence of occupational asthma associated with cleaning products exposure was (12\%) of the confirmed cases of work-related asthma (Rosenman et al. 2003) so sample size calculated by Epi6 program to be 711 with $10 \%$ nonresponder rate so sample was 780 with power of study $80 \%$ and confidence level $95.0 \%$. Multi-stage sampling technique was used for selection of participants. Two factories were selected, and then attendance sheet of workers was used to select the participant from each factory.

Inclusion criteria: male and female workers who were working at least for 1 year aged from 18 to 60 years old.

Exclusion criteria: workers with history of respiratory problems before joining their current work and who refuse to participate in the study.

\section{Study procedures}

Each participant was subjected to the following:

1-A semi-structured questionnaire was used depending on previous studies regarding sociodemographic, work characteristics, and asthma symptoms:

-Age, sex, smoking, occupational process, PPE, and duration

-Symptoms (cough, dyspnea, wheeze), symptoms resolve after work or in holidays or not, completely or partially trigger of asthma, asthma symptoms leading to night awaking, family history of atopy, childhood asthma, occupational periodic examination, diagnosed as occupational asthma, work replacement or compensation for occupational asthma (Nicholsonet al., 2001; Ladics et al., 2014; Porsbjerg et al., 2018).

2-Clinical examination.

3-Chest X-ray: if indicated to exclude other lesions. Portable X-ray machine was used in the workplace.

4-Spirometer: According to GINA guidelines (Reddel et al., 2015), participants were asked to perform forced expiratory maneuver where three reproducible curves were obtained $( \pm 5 \%)$. The spirometry was done from 8 to $11 \mathrm{am}$. The measured parameters included FVC, FEV1, FEV1\%, and PEFR.

5-Bronchodilator test: the test was done for all participants.

All examinations were done at the workplace in a special room in each factory used during the period of the field study.

Considerations for conducting spirometry during COVID19 (CDC 2020):

-Screen the workers before conducting the spirometry test: by taking their temperature and examining for potential COVID-19 symptoms such as chills, cough, sore throat, loss of taste or smell, runny nose, and nasal congestion.

-Staff used N95 mask and face shield.

-All workers used a face mask.

-Seventy percent alcohol was available for washing hands (for workers and staff) prior to and at the end of spirometry.

-Single-use nose clips and mouthpieces were used.

-Disinfection procedures were conducted after every worker. 


\section{Asthma Quality of Life Questionnaire (AQLQ) (Juniper et al., 1999)}

The questionnaire includes 32 items that assess asthma quality of life through the principal four domains which may be negatively affected by asthma.

-Asthma symptoms

-Activity limitations

-Emotional function

-Exposure to environmental stimuli

Every question is scored from 1 (severe impairment) to 7 (no impairment), and the total score is the mean of these four scores.

\section{Statistical analysis}

Data collected were coded and entered using Microsoft Excel software and Statistical Package for the Social Sciences (SPSS version 20.0) used for analysis. Qualitative data was represented as number and percentage, quantitative continues group by mean $\pm \mathrm{SD}$, testing association and differences of qualitative data by Chi square test (X2), while differences between quantitative independent groups by $\mathrm{t}$ test. Multiple logistic regression analysis was carried out to identify independent risk factors of occupational asthma. $P$-value was significant at $<0.05$ for significant results.

\section{Results}

Most of the included participants were males (76.2\%); the participants' age ranged from 21 to 56 years with mean age of 36.43 years, and mean duration of work was 7.79 years. $88.2 \%$ of them were manual workers, and $11.8 \%$ were working as observers. Majority of participants were married (74.7\%), and $24 \%$ were smokers (all smokers were males). The history of atopy was positive in $17.7 \%$ of our studied group, while only $7.8 \%$ of them is the use of protective measures as shown in Table 1.

The prevalence of occupational asthma among the studied workers was $35.4 \%$. $23.7 \%$ of participants were previously diagnosed as occupational asthma, while the new cases were $11.7 \%$ of participants as shown in Table 2.

The occupational asthma was prevalent among female workers; $25.3 \%$ of females were previously diagnosed with OA compared to $23.2 \%$ of males, while $16.7 \%$ of females were newly diagnosed with OA compared to $10.1 \%$ of males with statistically significant difference $(p<0.05)$ as shown in Fig. 1.

According to Gina guidelines, $58.4 \%$ of workers who were previously diagnosed with occupational asthma were
Table 1 Sociodemographic and work characteristics among studied worker of detergent and cleaning products $(N=780)$

\begin{tabular}{|c|c|c|c|}
\hline \multirow[t]{2}{*}{ Age (years) } & Mean \pm SD & \multicolumn{2}{|c|}{$36.43 \pm 9.35$} \\
\hline & Median (range) & \multicolumn{2}{|c|}{$35.0(21-56)$} \\
\hline \multirow[t]{3}{*}{ Duration of work (years) } & Mean \pm SD & \multicolumn{2}{|c|}{$7.79 \pm 3.86$} \\
\hline & Median (range) & \multicolumn{2}{|c|}{$9.0(1-25)$} \\
\hline & & $\mathbf{N}$ & $\%$ \\
\hline \multirow[t]{2}{*}{ Sex } & Female & 186 & 23.8 \\
\hline & Male & 594 & 76.2 \\
\hline \multirow[t]{2}{*}{ Occupation } & Manual & 688 & 88.2 \\
\hline & Observer & 92 & 11.8 \\
\hline \multirow[t]{3}{*}{ Marital state } & Married & 583 & 74.7 \\
\hline & Single & 182 & 23.3 \\
\hline & Widow & 15 & 1.9 \\
\hline \multirow[t]{2}{*}{ History of atopy } & $-\mathbf{V E}$ & 642 & 82.3 \\
\hline & $+V E$ & 138 & 17.7 \\
\hline \multirow[t]{2}{*}{ Smoking } & No & 593 & 76 \\
\hline & Smoker & 187 & 24 \\
\hline \multirow[t]{2}{*}{ Use of protective measures } & No & 719 & 92.2 \\
\hline & Yes & 61 & 7.8 \\
\hline
\end{tabular}

All smokers were males; no periodic medical examination for workers was done.

Table 2 Prevalence of occupational asthma among the studied workers

\begin{tabular}{lll}
\hline & No (780) & $\%$ \\
\hline Prevalence of occupational asthma & 276 & 35.4 \\
$\begin{array}{l}\text { Workers previously diagnosed with occupational } \\
\text { asthma }\end{array}$ & 185 & 23.7 \\
Workers newly diagnosed with occupational asthma & 91 & 11.7 \\
Workers free of occupational asthma & 504 & 64.6 \\
\hline
\end{tabular}

uncontrolled. FEV1/FVC was normal in $49.7 \%$, whereas $42.1 \%$ reported obstructive and $8.1 \%$ reported obstructive with mild restrictive symptoms. Regarding FEV1, 49.7\% were normal, while $41.6 \%$ and $8.6 \%$ had mild and moderate symptoms, respectively. $66.5 \%$ of these workers were on long-term treatment, and $82.7 \%$ of them changed their nature of work due to asthma. $50.3 \%$ of them had other allergy symptoms such as allergic rhinitis (Table 3 ).

Manually working and positive history of atopy were significantly associated with development of occupational asthma, while age, duration of work, smoking, and use of protective measure were not significantly associated with development of occupational asthma among our studied participants as shown in Table 4.

Multivariate logistic regression analysis revealed that female gender [odds ratio 1.397; 95\% CI 1.09-1.96], 
Fig. 1 Gender distribution of occupational asthma among the studied workers. Note: $X^{2}=4.58$, $P$-value $=0.032$ (statistical significant difference)

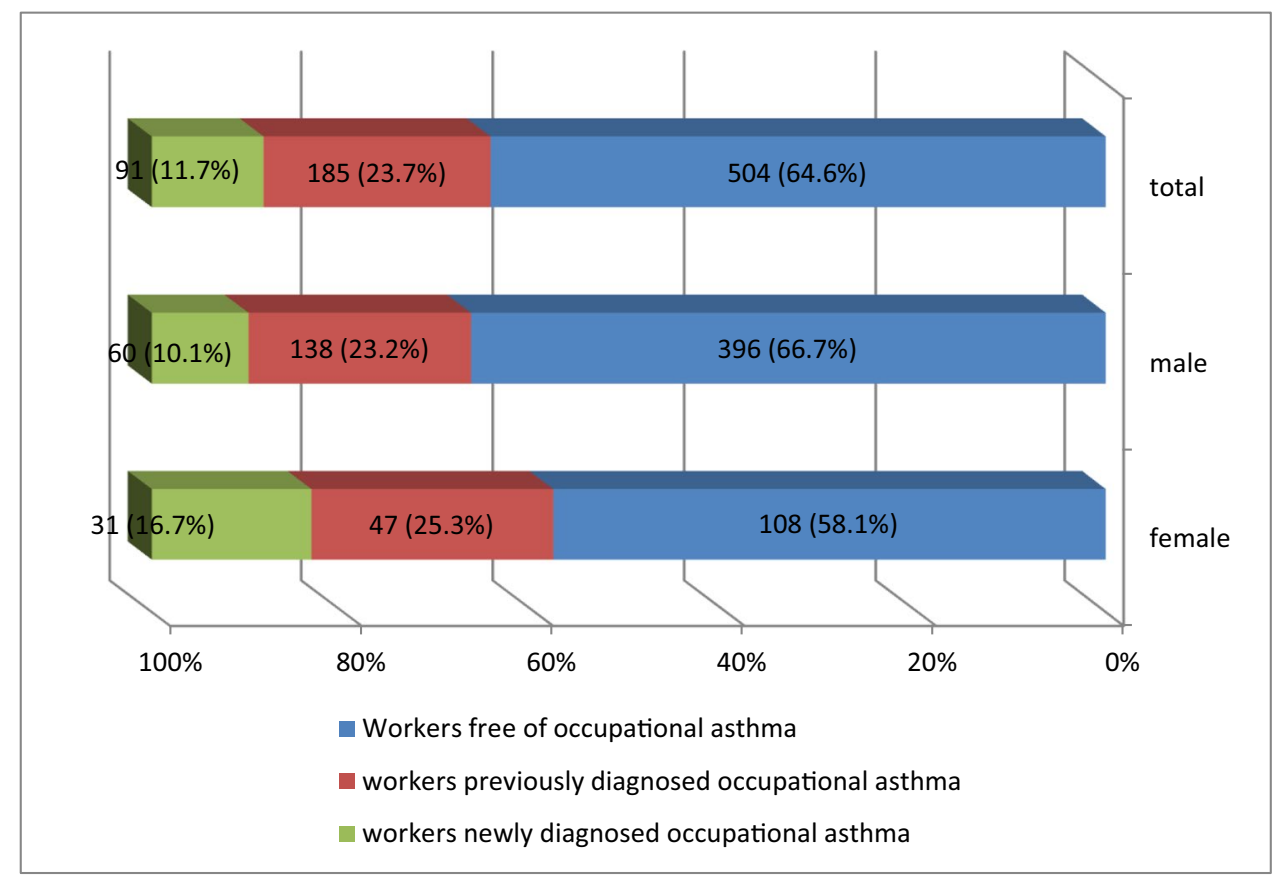

Table 3 Clinical characters of the previously diagnosed workers with occupational asthma $(N=185)$

\begin{tabular}{lllr}
\hline Duration & Mean \pm SD & \multicolumn{2}{l}{$6.45 \pm 2.26$} \\
\cline { 3 - 4 } & Median (Range) & \multicolumn{2}{l}{$5.0(2-12)$} \\
\cline { 3 - 4 } & & $\mathrm{N}$ & $\%$ \\
\hline Control of asthma according & Controlled & 77 & 41.6 \\
to Gina guidelines & Uncontrolled & 108 & 58.4 \\
FEV1/FVC & Normal & 92 & 49.7 \\
& Obstructive & 78 & 42.1 \\
& Obstructive with & 15 & 8.1 \\
FEV1 & mild restrictive & & \\
& Normal & 92 & 49.7 \\
& Mild & 77 & 41.6 \\
Long-term treatment & Moderate & 16 & 8.6 \\
& No & 123 & 66.5 \\
Change work due to asthma & YES & 62 & 33.5 \\
& No & 153 & 82.7 \\
Other site of allergy & Yes & 32 & 17.3 \\
& No & 92 & 49.7 \\
& Allergic rhinitis & 93 & 50.3 \\
\hline
\end{tabular}

manually working participants [odds ratio $3.067 ; 95 \% \mathrm{CI}$ $1.72-5.46$ ], and history of atopy [odds ratio 1.596; $95 \%$ CI 1.09-2.33] were risk factors for development of occupational asthma among worker in detergent and cleaning products as shown in Table 5 .

The average scores of the components of asthma-specific quality of life showed the lower score (indicating higher difficulty), while the higher score (indicating better quality). On comparing these components between asthmatic and non-asthmatic workers, among asthmatic workers, the mean score of symptoms $(4.52 \pm 0.84)$, activity limitations $(4.53 \pm 0.86)$, and exposure to environmental stimuli $(5.78 \pm 0.49)$ were lower than that of non-asthmatic $(5.94 \pm 0.51,6.07 \pm 0.60$, and $5.93 \pm 0.66$, respectively) with statistically significant difference $(P<0.01)$, while there is no statistical difference between them as regarding emotional function. The total mean score of asthma-specific quality of life was significantly lower in asthmatic $(5.10 \pm 0.49)$ than non-asthmatic workers $(5.89 \pm 0.46)(P<0.01)$ as shown in Table 6.

*Statistically significant $(P<0.05)$.

**Highly statistically significant $(P<0.001)$.

\section{Discussion}

Workers in detergent and cleaning products industry are vulnerable group for developing occupational asthma and other respiratory problems as they are exposed to a wide range of irritants and sensitizers in the chemical substances used, besides common indoor allergens and pollutants (Quirce \& Barranco, 2010).

It is essential to get an appropriate diagnosis of occupational asthma in workers. The disorder has serious health effects for affected individuals, as well as major socioeconomic consequences for both workers and employers. Missing an OA diagnosis can lead to extended exposure to 
Table 4 Association between sociodemographic and work characteristics and occupational asthma among the studied worker of detergent and cleaning products

\begin{tabular}{|c|c|c|c|c|c|}
\hline & & $\begin{array}{l}\text { Workers without occupa- } \\
\text { tional asthma }(N=504)\end{array}$ & $\begin{array}{l}\text { Workers with occupational } \\
\text { asthma }(N=276)\end{array}$ & Sig. test & $P$ value \\
\hline Age (years) & & $36.17 \pm 9.22$ & $36.92 \pm 9.57$ & $t=1.071$ & 0.285 \\
\hline Duration of work (years) & & $8.03 \pm 2.96$ & $7.76 \pm 2.38$ & $t=1.718$ & 0.091 \\
\hline \multirow[t]{2}{*}{ Occupation } & Manual & $427(84.7 \%)$ & $261(94.6 \%)$ & $X^{2}=16.60$ & $<0.001 * *$ \\
\hline & Observer & $77(15.3 \%$ & $15(5.4 \%)$ & & \\
\hline \multirow[t]{2}{*}{ History of atopy } & Negative & $427(84.7 \%)$ & $215(77.9 \%)$ & $X^{2}=5.71$ & $0.017 *$ \\
\hline & Positive & $77(15.3 \%)$ & $61(22.1 \%)$ & & \\
\hline \multirow[t]{2}{*}{ Smoking } & Non-smoker & $374(74.2 \%)$ & $219(79.3 \%)$ & $X^{2}=2.58$ & 0.108 \\
\hline & Smoker & $130(25.8 \%)$ & $57(20.7 \%)$ & & \\
\hline \multirow[t]{2}{*}{ Use of protective measure } & No & $468(92.9 \%)$ & $251(90.9 \%)$ & $X^{2}=0.90$ & 0.34 \\
\hline & Yes & $36(7.1 \%)$ & $25(9.1 \%)$ & & \\
\hline
\end{tabular}

All smokers were males.

*Statistically significant $(P<0.05)$.

**Highly statistically significant $(P<0.001)$.

Table 5 Multivariate logistic regression analysis of risk factors associated with occupational asthma among the studied worker of detergent and cleaning products
Table 6 Quality of life between workers with occupational asthma and others without occupational asthma

\begin{tabular}{lllrllll}
\hline Risk factors & B & S.E & Wald & Significance & OR & \multicolumn{2}{l}{$\begin{array}{l}\text { 95\% C.I } \\
\text { OR }\end{array}$} \\
\cline { 3 - 8 } & & & & & & LL & UL \\
\hline Positive history of atopy & 0.467 & 0.194 & 5.814 & $0.016^{*}$ & 1.596 & 1.091 & 2.33 \\
Manually working & 1.121 & 0.294 & 14.512 & $0.000^{* *}$ & 3.067 & 1.723 & 5.46 \\
Female gender & 0.434 & 0.175 & 5.662 & $0.047^{*}$ & 1.397 & 1.092 & 1.96 \\
\hline
\end{tabular}

$L L$ lower limit, $U L$ upper limit.

*Statistically significant $(P<0.05)$.

**Highly statistically significant $(P<0.001)$.

\begin{tabular}{|c|c|c|c|c|}
\hline & $\begin{array}{l}\text { Workers without occupa- } \\
\text { tional asthma }(N=504)\end{array}$ & $\begin{array}{l}\text { Workers with occupational } \\
\text { asthma }(N=276)\end{array}$ & $t$ & $p$ \\
\hline \multicolumn{5}{|l|}{ Symptoms } \\
\hline Mean \pm SD & $5.94 \pm 0.51$ & $4.52 \pm 0.84$ & & \\
\hline Range (max-min) & $3(4-7)$ & $5(2-7)$ & 25.47 & $0.000 * *$ \\
\hline \multicolumn{5}{|l|}{ Activity limitations } \\
\hline Mean \pm SD & $6.07 \pm 0.60$ & $4.53 \pm 0.86$ & & \\
\hline Range (max-min) & $4(3-7)$ & $5(2-7)$ & 26.33 & $0.000 * *$ \\
\hline \multicolumn{5}{|l|}{ Emotional function } \\
\hline Mean \pm SD & $5.60 \pm 0.94$ & $5.56 \pm 0.96$ & & \\
\hline Range (max-min) & $3(4-7)$ & $3(4-7)$ & 0.53 & 0.59 \\
\hline \multicolumn{5}{|c|}{ Exposure to environmental stimuli } \\
\hline Mean \pm SD & $5.93 \pm 0.66$ & $5.78 \pm 0.49$ & & \\
\hline Range (max-min) & $3(4-7)$ & $3(3-6)$ & 3.44 & $0.001 *$ \\
\hline \multicolumn{5}{|l|}{ Total } \\
\hline Mean \pm SD & $5.89 \pm 0.46$ & $5.10 \pm 0.49$ & & \\
\hline Range (max $-\min )$ & $2.5(4.5-7)$ & $2.50(3.75-6.25)$ & 21.6 & $0.000 * *$ \\
\hline
\end{tabular}


a causal agent and disease progression (Vandenplas et al., 2017).

In the present study, the diagnosis of OA was based on GINA guidelines including a history taking of exposure, respiratory symptoms and clinical examinations, spirometry, chest X-ray, and bronchodilator test. Our study revealed that $35.4 \%$ was the prevalence of occupational asthma; $23.7 \%$ of studied workers were previously diagnosed, while the new cases were $11.7 \%$. The high prevalence of occupational asthma among this workers are explained by that cleaning agents and detergents contain irritants like chlorine and ammonia, as well as possible sensitizers including quaternary ammonium compounds and fragrances (Dumas and Moual, 2016).

Vandenplas et al. (2013) conducted a retrospective case series of workers with work-related asthma who worked in the cleaning products industry. Thirty-nine percent of the workers were diagnosed positive for asthma caused by cleaning agents. Bleach was the most frequently attributed cleaning agent with asthma symptoms (Vandenplas et al., 2013).

Both allergic and irritating processes are implicated in asthma development caused by cleaning chemicals and disinfectants; however, the irritant mechanisms are the most prominent (Siracusa et al. 2013; Matteis and Cullinan, 2015). When the airway epithelium is damaged as a result of repeated irritating exposure, the inflammatory $\mathrm{Th} 2$ response is triggered (Tarlo \& Lemiere, 2014).

Several sociodemographic and work characteristics are associated with increased risk of developing occupational asthma. In the present study, female gender was significantly associated with development of occupational asthma $(p<0.05)$. Similarly, Torén et al. (2011) reported that occupational asthma was shown to be more common in women than it was in men. Cleaning agent exposure, both at home and at work, enhanced the risk (OR 2.0, 95\% CI 1.2-3.3) (Le Moual et al., 2013).

In our study, a significant association was noticed between manually working and occupational asthma than observers as manually working has a direct contact with the chemical and hence more exposure rate.

In the present study, positive history of atopy was significantly associated with development of occupational asthma. It may contribute to concurrent exposure to a mixture of enzymes in the detergent industry, and it is likely to have a synergistic effect in augmenting respiratory allergy (Hole et al., 2000). Basketter et al. (2012) reported that surveillance of detergent workers had led them to certain conclusions about the relationship between enzyme exposure, IgE antibody induction, and the elicitation of asthma symptoms (Basketter et al., 2012).

The implementation of exposure control tools resulted in a significant reduction in exposure; this resulted in the elimination of symptoms among IgE-positive workers as well as low rates of new sensitization in the workforce (Larsen et al., (2020). But, in our study, the use PPE was not significantly associated with asthma development as only $7 \%$ of our workers used PPE; this explain the high prevalence of occupational asthma among our studied group.

In occupational frameworks, smoking is one of the risk factors responsible to accelerate the process of occupational asthma maturity due to the combination bond of smoking, and occupational irritants exposure is significant for developing OA (Badar et al., 2016). Our study revealed non-significant association between OA and smoking as only $20 \%$ of our studied workers were smokers and all of them were males; no smoking among females, so association was difficult to be detected.

Occupational asthma can disrupt a patient's daily life, interfering with professional, familial, and social activities. It is also associated with a high rate of prolonged work disruption and income loss (Vandenplas and D'Alpaos 2010). Asthma-related QoL refers to the global impact of asthma and its management on physical, emotional, and social aspects of patients' functioning (Baiardini et al., 2006).

In our study, on comparing the subscales of asthmarelated quality of life between asthmatic and non-asthmatic workers, among asthmatic workers, the mean scores of symptoms, activity limitations, and exposure to environmental stimuli were lower than that of non-asthmatic with statistically significant difference $(P<0.01)$ referring to lower quality of life among asthmatic regarding these domains. But there is no statistical difference between them as regarding emotional function. The total mean score of asthma-specific quality of life was significantly lower in asthmatic than non-asthmatic workers $(P<0.01)$.

Malo et al. (1993) revealed a statistically significant difference was observed in all QoL domains (asthma symptoms, emotional dysfunction, limitation of activities, and environmental stimuli) moreover, in the total score of the quality of life. It was also reported that workers with OA, even when occupational exposure was ceased, have a slightly but significantly lower QoL than those without OA.

Miedinger et al. (2011) investigated individuals with OA 2 years after being removed from the causative agent and found that $35 \%$ of patients with OA had anxiety problems and $23 \%$ had dysthymia (a chronic form of depression). They also reported that patients with OA experienced higher levels of psychological distress and moderately reduced disease-specific QOL. 


\section{Conclusion}

Workers in detergent and cleaning products industry are at higher risk for developing occupational asthma. Cleaning products contain chemical substances that could contribute to the development of occupational asthma or exacerbate the symptoms among asthmatics due to respiratory tract irritation or sensitization mechanisms that adversely affect their general health and quality of life. Use of personal protective equipment at work and periodic medical examination could be solutions to protect workers from developing occupational asthma.

Acknowledgements The authors would like to thank all participants of this study for their great cooperation.

Author contribution Amani S. Ahmed, Wael G. Abd-El-Azem, Dalia A. Ibrahim, and Tarek H. Hassan were responsible for the study and contributed to the study's conception and design. Data collection was performed by Wael G. Abd-El-Azem, Dalia A. Ibrahim, and Tarek H. Hassan. Methodology and results were performed by Wael G. AbdEl-Azem and Amani S. Ahmed. Introduction and discussion were performed by Amani S. Ahmed. The manuscript was revised by Amani S. Ahmed. All authors read and approved the final manuscript.

Funding Open access funding provided by The Science, Technology \& Innovation Funding Authority (STDF) in cooperation with The Egyptian Knowledge Bank (EKB).

Availability of data and materials The datasets used and analyzed during this study are available from the corresponding author on reasonable request.

Ethical consideration.

The study protocol was approved by the Institutional Review Board (IRB) of Faculty of Medicine, Zagazig University. Approval from the workplace management team was obtained.

\section{Declarations}

Consent to participate Confidentiality and ethical considerations were respected. An informed verbal consent was obtained from all workers. They were told about the aim of our study, and the data would be used for scientific purposes only.

Consent to publish Authors have not published or submitted any related papers from the same study, and it is not under consideration for publication elsewhere. This original research article was submitted for consideration for publication in your Journal.

Competing of interest The authors declare no competing interests.

Open Access This article is licensed under a Creative Commons Attribution 4.0 International License, which permits use, sharing, adaptation, distribution and reproduction in any medium or format, as long as you give appropriate credit to the original author(s) and the source, provide a link to the Creative Commons licence, and indicate if changes were made. The images or other third party material in this article are included in the article's Creative Commons licence, unless indicated otherwise in a credit line to the material. If material is not included in the article's Creative Commons licence and your intended use is not permitted by statutory regulation or exceeds the permitted use, you will need to obtain permission directly from the copyright holder. To view a copy of this licence, visit http://creativecommons.org/licenses/by/4.0/.

\section{References}

Adisesh A, Murphy E, Barber CM, Ayres JG (2011) Occupational asthma and rhinitis due to detergent enzymes in healthcare. Occup Med 61(5):364-369. https://doi.org/10.1093/occmed/kqr107

Badar S, Ahmed SW, Mahmood ZA, Khaliq SA, Azhar I, Younus I (2016) Occupational asthma: contribution of smoking and hereditary effects. Iran J Public Health 45(7):956

Baiardini I, Braido F, Brandi S, Canonica GW (2006) Allergic diseases and their impact on quality of life. Ann Allergy Asthma Immunol 97(4):419-429. https://doi.org/10.1016/S1081-1206(10)60928-3

Basketter D, Berg N, Kruszewski FH, Sarlo K, Concoby B (2012) Relevance of sensitization to occupational allergy and asthma in the detergent industry. J Immunotoxicol 9(3):314-319. https:// doi.org/10.3109/1547691X.2012.656855

Baur X, Bakehe P (2014) Allergens causing occupational asthma: an evidence-based evaluation of the literature. Int Arch Occup Environ Health 87(4):339-363. https://doi.org/10.1007/ s00420-013-0866-9

Centers for disease control and prevention (2020): Conducting Spirometry during COVID-19. Acceded May 2020 available at https://www.cdc.gov/niosh/topics/cwhsp/makeroutine.html

De Matteis S, Cullinan P (2015) Occupational asthma in cleaners: a challenging black box. Occup Environ Med 72(11):755-756. https://doi.org/10.1136/oemed-2015-102985

Dumas O, Le Moual N (2016) Do chronic workplace irritant exposures cause asthma? Curr Opin Allergy Clin Immunol 16(2):7585. https://doi.org/10.1097/ACI.0000000000000247

Dykewicz MS (2009) Occupational asthma: current concepts in pathogenesis, diagnosis, and management. Journal of Allergy and Clinical Immunology 123(3):519-528. https://doi.org/10. 1016/j.jaci.2009.01.061

Eisner MD, Katz PP, Lactao G, Iribarren C (2005) Impact of depressive symptoms on adult asthma outcomes. Ann Allergy Asthma Immunol 94(5):566-574. https://doi.org/10.1016/S10811206(10)61135-0

Folletti I, Siracusa A, Paolocci G (2017) Update on asthma and cleaning agents. Curr Opin Allergy Clin Immunol 17(2):90-95. https://doi.org/10.1097/ACI.0000000000000349

Hole AM, Draper A, Jolliffe G, Cullinan P, Jones M, Taylor AN (2000) Occupational asthma caused by bacillary amylase used in the detergent industry. Occup Environ Med 57(12):840-842. https://doi.org/10.1136/oem.57.12.840

Juniper EF, Buist AS, Cox FM, Ferrie PJ, King DR (1999) Validation of a standardized version of the Asthma Quality of Life Questionnaire. Chest 115(5):1265-1270. https://doi.org/10. 1378/chest.115.5.1265

Ladics GS, Fry J, Goodman R, Herouet-Guicheney C, HoffmannSommergruber K, Madsen CB, Wal JM (2014) Allergic sensitization: screening methods. Clinical Translational Allergy 4(1):1-18. https://doi.org/10.1186/2045-7022-4-13

Larsen AI, Cederkvist L, Lykke AM, Wagner P, Johnsen CR, Poulsen LK (2020) Allergy development in adulthood: an occupational cohort study of the manufacturing of industrial enzymes. J Allergy Clinical Immunology Practice 8(1):210-218. https:// doi.org/10.1016/j.jaip.2019.06.007 
Lavoie KL, Joseph M, Bacon SL (2009) Psychological distress and occupational asthma. Curr Opin Allergy Clin Immunol 9(2):103-109. https://doi.org/10.1097/ACI.0b013e32832498c1

Le Moual N, Jacquemin B, Varraso R, Dumas O, Kauffmann F, Nadif R (2013) Environment and asthma in adults. La Presse Médicale 42(9):e317-e333. https://doi.org/10.1016/j.lpm.2013.06.010

Malo JL, Boulet LP, Dewitte JD, Cartier A, L'Archevêque J, Côté J, Guyatt GH (1993) Quality of life of subjects with occupational asthma. Journal of Allergy and Clinical Immunology 91(6):1121-1127. https://doi.org/10.1016/0091-6749(93) 90313-5

Miedinger D, Lavoie KL, L'Archevêque J, Ghezzo H, Zunzunuegui MV, Malo JL (2011) Quality-of-life, psychological, and cost outcomes 2 years after diagnosis of occupational asthma. J Occup Environ Med 53(3):231-238. https://doi.org/10.1097/ JOM.0b013e31820d1338

Moscato G, Pala G, Barnig C, De Blay F, Del Giacco SR, Folletti I, Van Wjik RG (2012) EAACI consensus statement for investigation of work-related asthma in non-specialized centres. Allergy 67(4):491-501. https://doi.org/10.1111/j.1398-9995. 2011.02784.x

Mwanga H, Jeebhay M (2013) Work-related asthma associated with cleaning agents in the health care setting-a review. health care 10:11. https://doi.org/10.13140/2.1.2307.6487

Nicholson PJ, Newman Taylor AJ, Oliver P, Cathcart M (2001) Current best practice for the health surveillance of enzyme workers in the soap and detergent industry. Occup Med 51(2):81-92. https://doi. org/10.1093/occmed/51.2.081

Porsbjerg C, Ulrik C, Skjold T, Backer V, Laerum B, Lehman S, Kankaanranta H (2018) Nordic consensus statement on the systematic assessment and management of possible severe asthma in adults. European Clinical Respiratory Journal 5(1):1440868. https://doi.org/10.1080/20018525.2018.1440868

Quirce S, Barranco P (2010) Cleaning agents and asthma. J Investig Allergol Clin Immunol 20(7):542-550

Radon K, Llanqui U, Arce A et al (2016) Job strain, bullying and violence at work and asthma in Peruvian cleaners-a cross-sectional analysis. J Asthma 53:1018-1025. https://doi.org/10.1080/02770 903.2016.1180698

Reddel HK, Bateman ED, Becker A, Boulet LP, Cruz AA, Drazen JM, FitzGerald JM (2015) A summary of the new GINA strategy: a roadmap to asthma control. Eur Respir J 46(3):622-639. https:// doi.org/10.1183/13993003.00853-2015

Richardson LP, Russo JE, Lozano P, McCauley E, Katon W (2008) The effect of comorbid anxiety and depressive disorders on health care utilization and costs among adolescents with asthma. Gen Hosp Psychiatry 30(5):398-406. https://doi.org/10.1016/j.genhosppsy ch.2008.06.004
Rosenman KD, Reilly MJ, Schill DP, Valiante D, Flattery J, Harrison R, Reinisch F, Pechter E, Davis L, Tumpowsky CM, Filios M (2003) Cleaning products and work-related asthma. J Occup Environ Med 45(5):556-563

Sarlo K, Kirchner DB, Troyano E, Smith LA, Carr GJ, Rodriguez C (2010) Assessing the risk of type 1 allergy to enzymes present in laundry and cleaning products: evidence from the clinical data. Toxicology 271(3):87-93. https://doi.org/10.1016/j.tox.2010.03. 007

Siracusa A, De Blay F, Folletti I, Moscato G, Olivieri M, Quirce S, Zock JP (2013) Asthma and exposure to cleaning products-a European Academy of Allergy and Clinical Immunology task force consensus statement. Allergy 68(12):1532-1545. https:// doi.org/10.1111/all.12279

Subbarao P, Mandhane PJ, Sears MR (2009) Asthma: epidemiology, etiology and risk factors. CMAJ 181(9):E181-E190. https://doi. org/10.1503/cmaj.080612

Svanes Ø, Skorge TD, Johannessen A, Bertelsen RJ, Bråtveit M, Forsberg B, Svanes C (2015) Respiratory health in cleaners in Northern Europe: is susceptibility established in early life? PLoS ONE 10(7):e0131959. https://doi.org/10.1371/journal.pone.0131959

Tarlo SM, Lemiere C (2014) Occupational asthma. N Engl J Med 370(7):640-649. https://doi.org/10.1056/NEJMra1301758

Torén K, Ekerljung L, Kim JL, Hillström J, Wennergren G, Rönmark E, Lundbäck B (2011) Adultonset asthma in west Sweden-incidence, sex differences and impact of occupational exposures. Respir Med 105(11):1622-1628. https://doi.org/10.1016/j.rmed.2011.06.003

Vandenplas O, Wiszniewska M, Raulf M, De Blay F, Gerth van Wijk R, Moscato G, Walusiak-Skorupa J (2014) EAACI position paper: irritant-induced asthma. Allergy 69(9):1141-1153. https://doi.org/ 10.1111/all.12448

Vandenplas O, Suojalehto H, Cullinan P (2017) Diagnosing occupational asthma. Clin Exp Allergy 47(1):6-18. https://doi.org/10. 1111/cea.12858

Vandenplas, O., \& D'Alpaos, V. (2010). Social consequences and quality of life in work-related asthma. In Occupational asthma (pp. 271-279). Birkhäuser Basel.'. https://doi.org/10.1007/978-3-76438556-9_15

Vandenplas, O., D'Alpaos, V., Evrard, G., Jamart, J., Thimpont, J., Huaux, F., \& Renauld, J. C. (2013). Asthma related to cleaning agents: a clinical insight. BMJ open, 3(9). https://doi.org/10.1136/ bmjopen-2013-003568

Publisher's Note Springer Nature remains neutral with regard to jurisdictional claims in published maps and institutional affiliations. 